\title{
Ruby laser transmission and the lens
}

\author{
A. R. ELKINGTON AND G. K. WATTS \\ Institute of Ophthalmology, University of London
}

The earliest recorded study of the transmission of light by the ocular media is attributed to Aschkinass (1895), but according to Meyer-Schwickerath (1960) his method was grossly inaccurate. Luckiesh (I92I) calculated the transmissivity of the ocular media on the basis that it equalled that of a layer of water $2.28 \mathrm{~cm}$. thick. Shoji (1923) and Bücklers (1926) both made measurements of transmission but the wavelengths used were all below $400 \mathrm{~m} \mu$.

In a classic paper, Ludvigh and McCarthy (1938) estimated the transmission of light of wavelengths from 400 to $820 \mathrm{~m} \mu$ to be 50 per cent. This paper is much quoted in the subsequent literature, and Davson ( 1963 ) quotes only the figure of 50 per cent. In fact Ludvigh and McCarthy based their estimate on experiments on only four eyes, all of which had been enucleated because they contained malignant melanomas. It can be reasonably argued that the ocular media may well have undergone pathological change while remaining clear to the naked eye.

The results of Ludvigh and McCarthy (1938) appear to have been accepted until 195I, when they were seriously questioned by Wald (I95I). At that time Meyer-Schwickerath (195 I), in developing his light-coagulator, became interested in the transmission of light by the ocular media; he repeated the experiments of Ludvigh and McCarthy (1938) and arrived at the same value of 50 per cent. However, he had no hesitation in discarding the results because the specimens used showed signs of post mortem change when examined critically.

Weale (1953), discussing the nature of light reaching the retinal elements after its passage through the ocular media, stated that "as far as the human eye is concerned, such knowledge is very inadequate in the case of the enucleated eye and non-existent in that of the eye in situ". Meyer-Schwickerath (1954) carried out further studies and calculated absorption values on the assumption that they were the same as that of $2 \cdot 28 \mathrm{~cm}$. water, quoting Goldmann, König, and Mader (1950) to justify this assumption. Such calculations showed that, at a wavelength of $694 \cdot 3 \mathrm{~m} \mu$, transmission via the ocular media was about 95 per cent.

Wiesinger, Schmidt, Williams, Tiller, Ruffin, Guerry, and Ham (1956) studied the transmission of light via the ocular media of nine freshly-enucleated rabbit eyes, using a spectrophotometer operating from 380 to $1,400 \mathrm{~m} \mu$. Their results also showed that, in the $694.3 \mathrm{~m} \mu$ range, transmission is of the order of 95 per cent. The technique appears to be free of major sources of error but, again, all the ocular media were grouped together in this study. There seems to be no work recorded in the literature in which the transmission of non-coherent light through the individual ocular media has been measured. Ham, Williams, Geeraets, Ruffin, and Mueller (1963) and Geeraets and Berry (1968) confirmed the figure of 95 per cent., again using non-coherent light. It may be concluded that the 
absorption of light in the lens alone is not more than 4 to 5 per cent. and presumably, since the lens is only one constituent of the ocular media, somewhat less.

There appears to be a universal assumption that the transmission of a laser beam through the ocular media is the same as that of a beam of light of the same wavelength. This may or may not be true, and an attempt has therefore been made to confirm this assumption by measuring the proportion of light energy from a ruby laser which is transmitted through the isolated lens.

\section{Apparatus and methods}

The lenses for these studies were all taken from healthy young adult rabbits. The following method of dissecting and mounting the lens was devised to preserve its optical properties by ensuring that it was not damaged or allowed to dry.

After enucleation the eye was washed, placed cornea downwards on filter paper, and held firmly with forceps by the stump of the optic nerve while four cuts were made in the sclera extending anteriorly to $\mathrm{I} \mathrm{mm}$. from the limbus. (This distance is important as the cornea must retain its shape in order to support the lens during the dissection.) The eye was then opened out as in Fig. I, care being taken to avoid contact with the lens (Fig. 2). Incisions were made with a razor blade across the base of all four flaps $\mathrm{I} \mathrm{mm}$. peripheral to the ciliary body, and penetrating the retina and choroid but not the sclera; the peripheral remnants of retino-choroidal tissue were then discarded, the central remnants being pushed up to the ciliary body, and the whole dissection was immersed in a Petri dish of silicone (Midland Silicone 200/10 cSt). Pulling up one portion of the choroid allowed a small incision to be made in the ciliary body through to the anterior chamber. Using small scissors, the ciliary body was completely freed from the sclera. Great care was taken to prevent damage to the lens surface. The ciliary body/iris/lens preparation was then inverted on the cornea (Fig. 2), and the iris was cut into quadrants. These cuts were ended $2 \mathrm{~mm}$. from the root of the iris to prevent the zonule from tearing. The quadrants were retracted and a suture passed through each
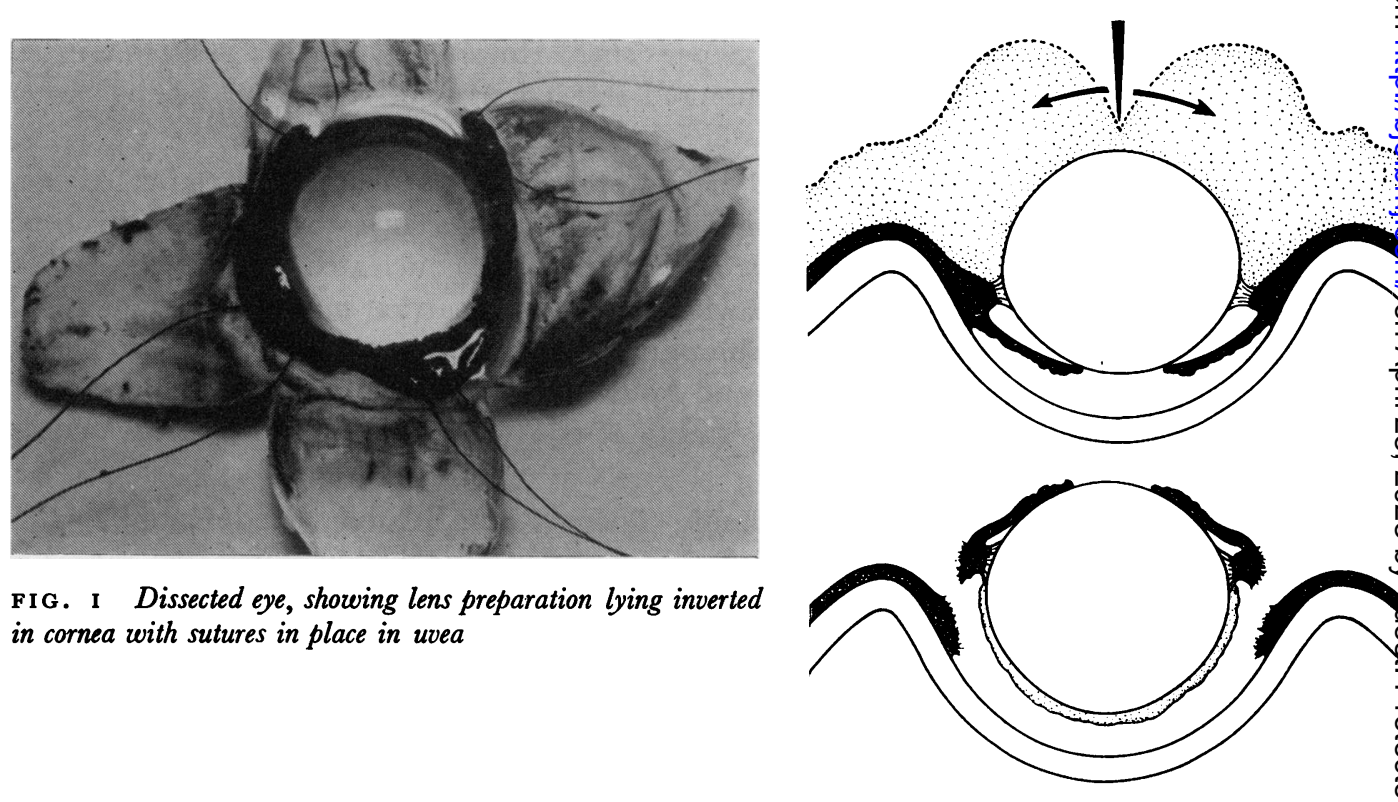

FIG. I Dissected eye, showing lens preparation lying inverted in cornea with sutures in place in uvea 
(Fig. I). A simple wire frame was clamped horizontally just above the preparation and the sutures were tied to each corner (Fig. 3). By touching the extreme periphery of the lens (now securely mounted in its frame) with a piece of filter paper and sweeping radially, the last of the vitreous was removed. The transparency of the lens could then be checked by slit-lamp inspection.

The lens was suspended in an optical cell having parallel front and rear surfaces and filled with silicone, thus avoiding any refraction or reflection at the lens surface. The cell was then positioned directly in front of a cone calorimeter (Laser Associates, Model 42) with an aperture of $24 \mathrm{~mm}$. The ruby laser source was mounted on a Gambs photo-slit-lamp (Hallman, Perkins, Watts, and Wheeler, 1968) positioned in front of the cell; the lens surface was thus clearly visible, the smallest aperture of the illuminating system being used to indicate that portion of the lens to be traversed by the beam. The laser was fired six times through different parts of each lens; this was then removed and six shots were fired through the cell, now filled only with silicone. All shots were fired at fixed time intervals to avoid overheating of the ruby. The insertion of the preparation into the cell obviously reduced the optical path of the beam through the silicone by a distance equal to the thickness of the lens, but the absorption by this layer of silicone was found to be so small that it could be ignored.

The calorimeter had a sensitivity of $235 \mu \mathrm{V} / \mathrm{J}$, and produced its peak voltage about I2 sec. after irradiation; in use, continuous recordings were made of its output for $20 \mathrm{sec}$. before and after firing the laser. By connecting the calorimeter to a circuit of constant resistance, it was possible to measure the current with an electronic galvanometer (John Fluke, Model 84 IA), giving a measure of the calorimeter output voltage. Calibration was done by incorporating a device in series with the galvanometer which generated a known voltage and also provided a means of zeroing the instrument by producing a constant but variable "backing-off" voltage. A continuous trace of the calorimeter's output and of the calibration signals was made possible by connecting an ultraviolet recorder to the galvanometer.

Results (see Table)

\begin{tabular}{|c|c|c|c|c|}
\hline \multirow{2}{*}{$\begin{array}{l}\text { Experi- } \\
\text { ment } \\
\text { no. }\end{array}$} & \multicolumn{2}{|c|}{$\begin{array}{l}\text { Calorimeter reading* } \\
\text { (Mean of six } \\
\text { exposures } m \mathcal{F} \text { ) }\end{array}$} & \multirow{2}{*}{$\begin{array}{l}\text { Differ- } \\
\text { ence } \\
\text { (per } \\
\text { cent. })\end{array}$} & \multirow{2}{*}{$\begin{array}{l}\mathrm{t} \text {-test } \\
\text { values }\end{array}$} \\
\hline & $\begin{array}{l}\text { Without } \\
\text { lens }\end{array}$ & $\begin{array}{l}\text { With } \\
\text { lens }\end{array}$ & & \\
\hline I & I $38 \cdot 3$ & $135 \cdot 7$ & $1 \cdot 9$ & $3 \cdot 8$ \\
\hline 2 & $127^{\circ} 0$ & $124^{\circ} 3$ & $2 \cdot I$ & $3 \cdot 5$ \\
\hline 3 & 118.8 & $108 \cdot 5$ & $2 \cdot 8$ & $11 \cdot 8$ \\
\hline 4 & $\mathrm{I} 35^{\circ} \mathrm{O}$ & I $31 \cdot 3$ & $2 \cdot 7$ & $4^{\cdot 8}$ \\
\hline 5 & $115 \cdot 8$ & 114.5 & $\mathbf{I} \cdot \mathbf{I}$ & $4 \cdot 7$ \\
\hline 6 & I $14^{\circ} \mathrm{O}$ & I I I 8 & $I \cdot 9$ & $4 \cdot 5$ \\
\hline 7 & 118.5 & I 15.8 & $I \cdot 9$ & $5 \cdot 7$ \\
\hline 8 & $102 \cdot 8$ & $100 \cdot 2$ & $2 \cdot 5$ & $3 \cdot 0$ \\
\hline 9 & $\log ^{\circ} 2$ & $106 \cdot 0$ & $2 \cdot 9$ & $6 \cdot 5$ \\
\hline 10 & $108 \cdot 2$ & $105^{\circ} 0$ & $3^{\circ} 0$ & $5^{\cdot 8}$ \\
\hline I I & $110 \cdot 7$ & $108 \cdot 0$ & $2 \cdot 4$ & $5 \cdot 4$ \\
\hline 12 & I I $2 \cdot 0$ & I09.5 & $2 \cdot 2$ & $7 \cdot 3$ \\
\hline I3 & $102 \cdot 8$ & $100 \cdot 0$ & $\begin{array}{l}2 \cdot 7 \\
2 \cdot 1\end{array}$ & $\begin{array}{l}0.1 \\
6.6\end{array}$ \\
\hline 14 & 107.5 & 105.2 & $2 \cdot I$ & 0.0 \\
\hline I 5 & $115^{\circ} 8$ & I 13.8 & $\begin{array}{l}1 \cdot 7 \\
0\end{array}$ & 4.5 \\
\hline 16 & $\begin{aligned} 118 \cdot 0 \\
0\end{aligned}$ & $\begin{array}{r}114.7 \\
06.8\end{array}$ & $\begin{array}{l}2 \cdot 8 \\
2 \cdot 2\end{array}$ & $\begin{array}{l}0 \cdot 7 \\
4 \cdot 8\end{array}$ \\
\hline $\begin{array}{l}17 \\
18\end{array}$ & $\begin{array}{r}99^{\circ} \mathrm{O} \\
\mathbf{1 0 5} 8\end{array}$ & $\begin{array}{r}96.8 \\
104.3\end{array}$ & $\begin{array}{l}2 \cdot 2 \\
1 \cdot 4\end{array}$ & $\begin{array}{l}4.0 \\
3.9\end{array}$ \\
\hline 19 & $94^{\circ} 8$ & $92 \cdot 8$ & $2 \cdot I$ & 5.6 \\
\hline \multirow[t]{2}{*}{20} & $103 \cdot 8$ & $101 \cdot 8$ & $I \cdot 9$ & $5 \cdot 6$ \\
\hline & & $\begin{array}{l}\text { Mean } \\
\text { S.D. }\end{array}$ & \multicolumn{2}{|c|}{$\begin{aligned} & 2.2 \text { per cent. } \\
\pm & 0.5 \mathrm{I}\end{aligned}$} \\
\hline
\end{tabular}

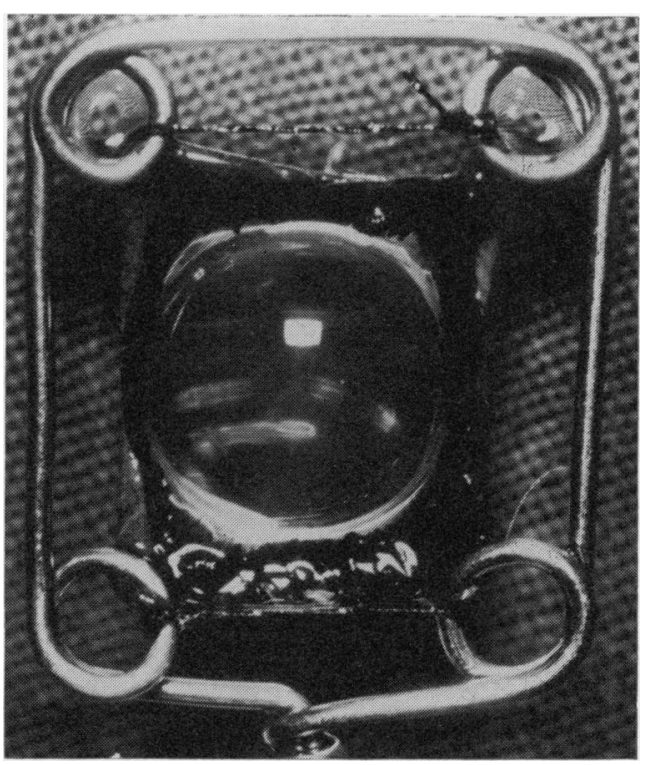

FIG. 3 Completed preparation mounted in wire frame

* Comparison between readings with and without the lens using Student's $t$-test showed a significant difference at the 0.05 level in each experiment. 


\section{Discussion}

In considering the accuracy of the transmission values obtained, it should be remembered that the output of any laser from shot to shot is variable, and that no facilities for monitoring the energy of each shot were available. The error arising from such variations was minimized by taking a mean of six readings of both values, but could not be completely excluded.

Khosla (1968), working in this Department and using similar methods to those employed here, found that the rabbit cornea absorbed $\mathrm{I} \cdot 6$ per cent. of light from a ruby laser beam. This value added to the 2.2 per cent. for the lens gives 3.8 per cent., leaving approximately I. 2 per cent. of the original 5 per cent. figure quoted for absorption in the ocular media. The remaining media, the aqueous and vitreous, if regarded as water would be expected to absorb about I $\cdot 2$ per cent. of light at a wavelength of $694 \cdot 3 \mu \mathrm{m}$.

The importance of the measurements obtained both in this study and in Khosla's work lies less in their absolute value (which could be measured more accurately using lower energy light sources and photoelectric measuring devices) than in the fact that together they differ little from figures produced by workers using non-coherent light sources. It would seem, therefore, that the absorption of light from a ruby laser by the rabbit lens is no greater than the absorption of ordinary red light. There is no reason to suppose that the human lens would behave differently.

No clinically visible effects on the lens have been observed with energies of $240 \mathrm{~mJ}$, but this does not exclude the possibility of cellular damage as demonstrated in the cornea by Parr and Fisher ( 1967 ). There is no reason to suppose that the young normal human lens would behave differently, though more light would be absorbed by older lenses and those with opacities.

\section{Summary}

A technique for measuring in vitro the transmission of the rabbit lens to ruby laser light at $694 \cdot 3 \mathrm{~m} \mu$ is described. The mean absorption value was found to be $2 \cdot 2$ per cent. (S.D. $\pm 0.5 \mathrm{I}$ ), suggesting that transmission figures derived from experiments using non-coherent light are also applicable to laser light.

We should like to thank Prof. E. S. Perkins for his valuable advice and encouragement, Mr. M. Bass for skilled technical assistance, and Mr. T. Tarrant of the Department of Audio-Visual Communications for the illustrations.

This work was aided by a grant from the Ministry of Defence.

\section{References}

aschrinass, E. (1895) Ann. Physik u. Chemie, n.s. 55, 4 O I

BüCKLERS, M. (1926) v. Graefes Arch. Ophthal., 117, I

Davson, H. (1963) "Physiology of the Eye", and ed. Churchill, London

GEERAETs, W. J., and BerRy, E. R. (1968) Amer. 7. Ophthal., 66, I 5

GOLDMANN, H., KöNIG, H., and MÄDER, F. (1950) Ophthalmologica (Basel), 120, 198

hallman, v. L., Perkins, E. S., WATts, G. K., and Wheeler, c. B. (1968) Exp. Eye Res., 7, 48 I

ham, W. T., JR., Williams, R. C., GEeraets, W. J., RUfFin, R. s., and MUELler, H. A. (1963) Acta ophthal. (Kbh.), Suppl. 76, p. 6o

кHosLA, P. K. (1968) Orient. Arch. Ophthal., 6, 312

LUCKIESH, м. (1921) Amer. F. physiol. Optics, 2, 3

LUdVigh, E., and McCARThy, E. F. (1938) Arch. Ophthal. (Chicago), 20, 37 
MEYER-SCHWICKERATH, G. (1951) Ber. dtsch. ophthal. Ges., 57, I 44

(1954) v. Graefes Arch. Ophthal., 156, 2

(1960) "Light Coagulation", trans. S. M. Drance. Kimpton, London

PARR, W. H., and FISHER, R. S. (I967) Invest. Ophthal., 6, 356

SHOJI, Y. (1923) Ann. Oculist. (Paris), 160, 356

WALD, G. (195I) Cited from Studnitz, G. von, "Physiologie des Sehens", 2nd ed. Akademische Verlagsgesellschaft, 1952. Leipzig

Weale, R. A. (1953) Brit. F. Ophthal., 37, 148

WIESINGER, H., SCHMIDT, F. H., WILLIAMS, R. C., TILLER, G. O., RUFFIN, R. S., GUERRY, DUPONT, III, and hам, W. т. (1956) Amer. F. Ophthal., 42, 907 